\title{
Enzyme-linked imunoassays for the detection of Listeria sp. and Salmonella sp. in sausage: A comparison with conventional methods
}

\author{
T.M. Benetti ${ }^{1}$, C.L.B. Monteiro ${ }^{1}$, M.R. Beux ${ }^{1}$, W.M. Abrahão ${ }^{2,3}$ \\ ${ }^{1}$ Universidade Federal do Paraná, Curitiba, PR, Brazil. \\ ${ }^{2}$ Universidade Federal do Paraná, Curitiba, PR, Brazil. \\ ${ }^{3}$ Laboratório Central do Estado do Paraná, Curitiba/PR, Brazil.
}

Submitted: January 13, 2012; Approved: September 10, 2012.

\begin{abstract}
This study was carried out comparing the conventional methods (ISO 11290-1 and BAM method, 2008) and system mini-Vidas ${ }^{\circledR}$ (Biomerieux), for detection of Listeria sp. and Salmonella sp. in cooled sausage. The immunoenzymatic method has shown to be effective for the detection of target pathogens, it has presented itself as an excellent screening method.
\end{abstract}

Key words: cooled sausage, Salmonella sp., Listeria sp., system mini-Vidas ${ }^{\circledR}$.

An appropriate and efficient method for detecting microorganisms in food has been constantly searched for by researchers (Giombelli, 2000). The choice of methodology to be adopted in conducting the microbiological analysis of any product should be guided by the following parameters: the desired accuracy, cost, time of analysis, acceptance of the method by official agencies and the scientific community, simplicity of operation, training, and the analyst's qualifications, availability of reagents, culture media and other supplies (Franco and Landgraf, 2008).

The detection of Salmonella sp. and Listeria sp. in food is often carried out by the traditional method designate classical method. Although they show some variations in the selection of culture media and in the form of sample preparation, they basically involve four steps that can be applied to any type food: pre-enrichment, selective enrichment, isolation on solid selective media, and complete identification of the colonies through biochemical and serological testing (Boer and Beumer, 1999; Giombelli and Lopes da Silva, 2002; Reis et al., 2002; Silva et al., 2004).

In recent years, several methods have been proposed for the rapid detection and among them there are the immunological techniques. The enzyme immunoassays (EIA) may contribute to accelerate and simplify the detection of various types of pathogens in foods (1) and are most commonly used because they present several advantages: sim- plicity, rapidity, sensitivity, specificity and convenience as a screening method (Franco and Landgraf, 2008).

The objective of this study was to compare results obtained with the conventional culture methods for detection of Listeria sp. (ISO standard 11290-1) (ISO, 1996) and Salmonella sp. (BAM method) (Hitchins, 2003) in a cold sausages, compared to the mini-Vidas ${ }^{\circledR}$ system, as well as identify the prevalence of colds sausage contaminated with Listeria monocytogenes and species of the genus Salmonella, and perform the evaluation of the analysis time waived for identification of Salmonella sp. and Listeria sp. to conventional methods (BAM and ISO) and rapid methods (mini-Vidas Listeria and mini-Vidas Salmonella) (Biomerieux).

We collected 51 samples of cold sausage purchased at different retailers in the state of Paraná, and produced in the southern region of Brazil. It was acquired by the sample, the minimum amount of $250 \mathrm{~g}$ in order to maintain the representative recommended by the RDC (Board Resolution) of 12 02/01/2001 (RDC, 2001).

In all evaluations characterized the presence and absence of pathogens in $25 \mathrm{~g}$ of sample tested. For the detection of Listeria sp. employed the ISO 11290-1 method (conventional method), and the system mini-Vidas ${ }^{\circledR}$ (Biomerieux). For the Salmonella sp. using the conventional method we used conventional methodology described in Bacteriological Analytical Manual (BAM) online 
(Hitchins, 2003), created by the Food and Drug Administration (FDA), Compendium of Methods for the Microbiological Examination of Foods (1992) and rapid method, using the system mini-Vidas ${ }^{\circledR}$ (Biomerieux).

The system mini-Vidas ${ }^{\circledR}$ is a method of qualitative automated enzyme immunoassay analysis that uses the technique ELFA (Enzyme Linked Flourescent Assay) consisting of a mixture of monoclonal capture antibodies with high specificity for antigen detection. All the test steps are performed automatically using disposable plastic galleries, consisting of compartments containing the reactants needed for the test. Therefore, the reading and interpretation of results are also automatic.

The conventional culture method for Listeria sp. consisted of: 01) Primary Enrichment: 25 g of sample were added $225 \mathrm{~mL}$ of Half Fraser broth supplemented with SR 0166E (Oxoid), this was incubated at $30{ }^{\circ} \mathrm{C}$ for $24 \mathrm{~h} .02$ ) Secondary Enrichment: $1 \mathrm{~mL}$ of primary enrichment was added to $9 \mathrm{~mL}$ of Fraser broth supplemented with SR 0155E (Oxoid) and incubated at $37^{\circ} \mathrm{C}$ for 48 h. 03) Selective Plating: it was the rifling in duplicate plating on selective media: Palcam agar supplemented with SR 0150E (Oxoid), Oxford agar selective for Listeria sp. supplemented with SR 0140E (Oxoid). The confirmation occurred after by rifling in tubes Triptycase soy agar supplemented with $0.6 \%$ yeast extract (TSA-YE) (Difco) and incubated at $30^{\circ} \mathrm{C} / 24$ to $48 \mathrm{~h}$. It was evaluated the motility characteristic umbrella tube using sulfide indol motility with addition of $0.05 \%$ chloride trifeniltetrazolium (Sigma ${ }^{\circledR}$ ) (SIM changed), and incubated at $25^{\circ} \mathrm{C}$ for up to 7 days and daily observation. The confirmation biochemical occurred in parallel with API Listeria system ${ }^{\circledR}$ (Biomerieux), according to the manufacturer's instructions.

Mini-Vidas ${ }^{\circledR}$ system Listeria sp. was developed from the $48 \mathrm{~h}$ of enrichment Fraser broth and subsequent inactivation cell occurred by transferring $2 \mathrm{~mL}$ sterile tube, heated in a water bath at $95^{\circ} \mathrm{C}-100^{\circ} \mathrm{C}$ for $15 \mathrm{~min}$, the tube was cooled immediately in a cold water bath. It was transferred $0.5 \mathrm{~mL}$ of the suspension to the well-inactivated sample LIS mini-Vidas ${ }^{\circledR}$ (Development of the methodology as recommended by the manufacturer). In this case we proceeded to the selective plating, biochemical identification, adopting the same methodology of the conventional procedure.

The conventional culture method for Salmonella sp. consisted of: 01) Pre-non-selective enrichment broth: $25 \mathrm{~g}$ of sample were added to $225 \mathrm{~mL}$ of pre-enrichment broth
(ADPT) and incubated at $35 \pm 0.2^{\circ} \mathrm{C}$ for $24 \mathrm{~h} .02$ ) Selective enrichment broth: $1.0 \mathrm{~mL}$ pre-enrichment broth was transferred to $10.0 \mathrm{~mL}$ of Selenite Cystine Broth (SC) and $0.1 \mathrm{~mL}$ to $10.0 \mathrm{~mL}$ of Rappaport-Vassiliadis Broth Soy Peptone (RVS) which were incubated at $42 \pm 0.2{ }^{\circ} \mathrm{C}$ for 24 h. 03) Selective Differential Plating: the selective enrichment broth was streaked on SS agar and HE agar incubated at $35 \pm 0.2{ }^{\circ} \mathrm{C}$ for $24 \mathrm{~h}$. The biochemical and serological confirmation occurred after plating tube LIA agar and TSI agar, incubated at $35 \pm 0.2{ }^{\circ} \mathrm{C}$ for $24 \mathrm{~h}$ and from these serologic testing performed in somatic polyvalent glass sheet. In addition the API 20E® system (Biomerieux) has been developed according to the manufacturer's instructions.

The mini-Vidas ${ }^{\circledR}$ system Salmonella sp. was performed from the secondary enrichment broth, where $1 \mathrm{~mL}$ of each broth was transferred to the broth $\mathrm{M}$, incubated at $42 \pm 0.2^{\circ} \mathrm{C}$ for $24 \mathrm{~h}$. The cell inactivation occurred by transferring $2 \mathrm{~mL}$ of the secondary enrichment for sterile tube, heated in a water bath at $95^{\circ} \mathrm{C}-100^{\circ} \mathrm{C}$ for $15 \mathrm{~min}$, the tube was cooled immediately in a cold water bath. It was transferred $0.5 \mathrm{~mL}$ of the suspension to the well-inactivated sample SLM mini-Vidas ${ }^{\circledR}$ (Development of the methodology as recommended by the manufacturer). In this case we proceeded to the selective plating, biochemical identification and serology, adopting the same methodology of the conventional procedure.

In statistical analysis we calculated the estimates of sensitivity, specificity, prevalence, false positive error rate and false negative error rate according to the model proposed by Hanrahan and Madupu (1994). For comparative analysis between the methods of pathogens mini-Vidas ${ }^{\circledR}$ and the conventional method the latter was considered as standard for pathogen identification.

Considering the two methods of analysis, the prevalence of Listeria sp. was $52.9 \%$, and of these, $13.7 \%$ corresponded of L. monocytogenes, whereas L. gray was reported in $19.7 \%$ and $L$. innocua and $L$. welshimeri were identified, $13.7 \%$ and $5.9 \%$ of cases respectively. The presence of Salmonella was recorded in $3.9 \%$ of samples.

In the study of Listeria sp. 28 samples were positive for methods ISO $11290-1$ and also the mini-Vidas ${ }^{\circledR}$ system, however, there was only one positive sample by the method mini-Vidas ${ }^{\circledR}$ (false positive), and one sample by the ISO method (false negative) (Table 1). Observing the comparative evaluation between the methodologies, a sen-

Table 1 - Positive results observed by mini-Vidas ${ }^{\circledR}$ method and conventional method for Salmonella sp. and Listeria sp. in cooled sausage

\begin{tabular}{lcccccc}
\hline \multirow{2}{*}{ Diagnosis } & \multicolumn{2}{c}{ Salmonella sp. } & & \multicolumn{2}{c}{ Listeria sp. } \\
\cline { 2 - 3 } \cline { 5 - 6 } & BAM standard & Mini-Vidas ${ }^{\circledR}$ & & ISO standard & Mini-Vidas ${ }^{\circledR}$ \\
\hline Prevalence & 06 & 11 & & 28 & 28 \\
Exclusive insulation & 0 & 05 & & 01 & 01 \\
\hline
\end{tabular}


sitivity of $96.7 \%$ and a specificity of $94.7 \%$ (Table 2 ) was found.

During the Salmonella sp. study 11 positive samples were verified by the system mini-Vidas ${ }^{\circledR}$ and only 06 for the methodology BAM, so 05 samples were positive only if the method mini-Vidas ${ }^{\circledR}$, considered these false positive (Table 1). There was the presence of false positives attributed by the detection of other bacteria, these belonging to the family Enterobacteriaceae. The method mini-Vidas ${ }^{\circledR}$ compared to the BAM method for identification of Salmonella sp. produced a sensitivity of $100 \%$ and a specificity of $88.89 \%$ (Table 2).

Comparing the response time of methods for identification of Salmonella sp., it was observed that the negative result is identified for both method (mini-Vidas ${ }^{\circledR}$ and Bam)

Table 2 - Comparison of results between the mini-Vidas ${ }^{\circledR}$ method and conventional method for Salmonella sp. and Listeria sp. in cooled sausage.

\begin{tabular}{lcc}
\hline Diagnosis & $\begin{array}{c}\text { Salmonella sp. (BAM } \\
\text { standard X } \\
\text { mini-Vidas } ®)\end{array}$ & $\begin{array}{c}\text { Listeria sp. (ISO stan- } \\
\text { dard X mini-Vidas } ®)\end{array}$ \\
\hline True positive & 6 & 31 \\
True negative & 40 & 18 \\
False positive & 5 & 1 \\
False negative & 0 & 1 \\
Sensibility & $100 \%$ & $96.80 \%$ \\
Specifciity & $88.89 \%$ & $94.70 \%$ \\
Prevalence & $11.76 \%$ & $62.74 \%$ \\
\hline
\end{tabular}

in $72 \mathrm{~h}$. However, in case of positive result mini-Vidas ${ }^{\circledR}$ method requires $24 \mathrm{~h}$ to more than the BAM method, this is, dispensation additional $24 \mathrm{~h}$ to the culture broth of the "M", used in the confirmatory method of mini-Vidas ${ }^{\circledR}$ (Table 3 ).

However for the study of Listeria sp., it was observed that the method mini-Vidas ${ }^{\circledR}$, presented a negative result in $48 \mathrm{~h}$, whereas the conventional method needs $120 \mathrm{~h}$. Nevertheless, the positive result would occur in $264 \mathrm{~h}$ by the method mini-Vidas ${ }^{\circledR}$ and $288 \mathrm{~h}$ by the ISO methodology. Considering that the international law determines absence of the genus Listeria, the rapid method mini-Vidas ${ }^{\circledR}$ provides an advantage over the conventional method ISO reducing the $72 \mathrm{~h}$ analysis (Table 4 ).

The mini-Vidas ${ }^{\circledR}$ method when compared to the ISO method, demonstrated that it is able to identify very low concentrations of viable microorganisms in the sample. It is noteworthy that a positive sample for Listeria sp. is not always pathogenic, causing part of this group only Listeria monocytogenes which corresponds to an incidence of only $13.7 \%$ of $53.9 \%$ of the total.

Lepper et al. (2002) developed a similar study conducted by comparing the system with the mini-Vidas ${ }^{\circledR}$ Salmonella, BAM classical culture in 6 types of products: milk chocolate, milk powder, egg powder, soy flour, black pepper and "raw land". The researcher noted that the two methods were concordant for 1266 of 1440 samples.

Blackburn et al. (2008) promoted the detection of Salmonella sp. using the mini-Vidas ${ }^{\circledR}$ system was compared with a conventional method for the detection of Salmonella sp. in 141 samples and naturally contaminated

Table 3 - Description of the analysis time for identification of Salmonella sp.

\begin{tabular}{|c|c|c|c|c|}
\hline & & Activity & Time worked & Total time \\
\hline \multirow[t]{7}{*}{ BAM } & \multirow[t]{3}{*}{ Result negative } & Pre-enrichment broth non selective & $24 \mathrm{~h}$ & $72 \mathrm{~h}$ ( 3 days) \\
\hline & & Seletive enrichment broth & $24 \mathrm{~h}$ & \\
\hline & & Selective and differential plating & $24 \mathrm{~h}$ & \\
\hline & \multirow[t]{4}{*}{ Result positive } & Pre-enrichment broth non selective & $24 \mathrm{~h}$ & $96 \mathrm{~h}$ (4 days) \\
\hline & & Seletive enrichment broth & $24 \mathrm{~h}$ & \\
\hline & & Selective and differential plating & $24 \mathrm{~h}$ & \\
\hline & & Culture TSI and LIA + serology & $24 \mathrm{~h}$ & \\
\hline \multirow{8}{*}{$\begin{array}{l}\text { Mini-Vidas }{ }^{\circledR} \\
\text { Salmonella }\end{array}$} & \multirow[t]{3}{*}{ Result negative } & Pre-enrichment broth non selective & $24 \mathrm{~h}$ & $72 \mathrm{~h}$ (3 days) \\
\hline & & Seletive enrichment broth & $24 \mathrm{~h}$ & \\
\hline & & $\begin{array}{l}\text { Seletive enrichment broth "M" }+ \text { cell inactivation }+ \text { insertion of the an- } \\
\text { tigen in the cap in mini-Vidas }{ }^{\circledR} \text { machine }\end{array}$ & $24 \mathrm{~h}$ & \\
\hline & \multirow[t]{5}{*}{ Result positive } & Pre-enrichment broth non selective & $24 \mathrm{~h}$ & $120 \mathrm{~h}(5$ days $)$ \\
\hline & & Seletive enrichment broth & $24 \mathrm{~h}$ & \\
\hline & & $\begin{array}{l}\text { Seletive enrichment broth "M" }+ \text { cell inactivation }+ \text { insertion of the an- } \\
\text { tigen in the cap in mini-Vidas }{ }^{\circledR} \text { machine }\end{array}$ & $24 \mathrm{~h}$ & \\
\hline & & Selective and differential plating & $24 \mathrm{~h}$ & \\
\hline & & Culture TSI and LIA + serology & $24 \mathrm{~h}$ & \\
\hline
\end{tabular}


Table 4 - Description of the analysis time for identification of Listeria sp.

\begin{tabular}{|c|c|c|c|c|}
\hline & & Activity & Time worked & Total time \\
\hline \multirow[t]{7}{*}{ ISO } & Result negative & Primary enrichment & $24 \mathrm{~h}$ & $120 \mathrm{~h}$ (5 days) \\
\hline & & Secondary enrichment & $48 \mathrm{~h}$ & \\
\hline & & Selective plating & $48 \mathrm{~h}$ & \\
\hline & Result positive & Primary enrichment & $24 \mathrm{~h}$ & $288 \mathrm{~h}$ (12 days) \\
\hline & & Secondary enrichment & $48 \mathrm{~h}$ & \\
\hline & & Selective plating & $48 \mathrm{~h}$ & \\
\hline & & Culture of Indol and evaluation for the motility & $168 \mathrm{~h}$ & \\
\hline Mini-Vidas ${ }^{\circledR}$ Listeria & Result negative & Primary enrichment & $24 \mathrm{~h}$ & $48 \mathrm{~h}$ (2 days) \\
\hline
\end{tabular}

foods. As a result there was an overall agreement of $92.9 \%$ between the methods.

In the present study it was found that the mini-Vidas ${ }^{\circledR}$ methodology was effective for the detection of target pathogens, and they presented themselves as excellent screening methods, so the present work contributes to the introduction of a faster method (especially when researching the pathogen Listeria sp.) with the reliability expected by analysts, developing this forms a new reality facing the accuracy of results, favoring the satisfaction of the producer to send to the market a safe product, providing advantages in marketing directly to consumers by ensuring more reliable products to be consumed.

\section{Acknowledgments}

We would like to thank de Secretaria de Estado da Saúde do Paraná and Laboratório Central do Estado do Paraná, as well as for the donation of the facilities and the sponsorship for the performance of the essays.

\section{References}

AOAC International (AOAC). Listeria monocytogenes - Chapter 15: In Official Methods of Analysis of AOAC International, 16th. ed., PA Cunniff, p. 94a-98. AOAC International, Gaithersburg, MD, 993.12, 1999; available in: http://seafood.ucdavis.edu/HACCP/Compendium/Chapt15.htm, access in April 2008.

Blackburn CW, Curtis LM, Humpheson L, Petitt SB (2008) Evaluation of the Vitek Immunodiagnostic Assay System (VIDAS) for the detection of Salmonella in foods. Lett Appl Microbiol 19:32-36.

Boer E, Beumer RR (1999) Methodology for detection and typing of foodborne microorganisms. Int $\mathrm{J}$ Food Microbiol 50:119-130.

Franco BDGM, Landgraf M (2008) Food Microbiology. São Paulo. Atheneu Editor.
Giombelli A (2000) Classical traditional method for detection of Salmonella in foods: A very complex technical problem. Revised Food Hygiene 14:58-61.

Giombelli A, Lopes da Silva N (2002) Evaluation of the traditional method for the detection of Salmonella spp. in raw meats. Revised Food Hygiene 14:88-91.

Hanrahan EJ, Madupu G (1994) Appleton \& Lange's review of epidemiology \& biostatistics for the USMLE. Edited by Hanrahan EJ, Madupu G. New Jersey: Prentice Hall. Englewood Cliffs.

Hitchins AD (2003) Detection and enumeration of Listeria monocytogenes in foods. In: U S Food and Drug Administration (FDA), Bacteriological Analytical Manual online, available in: http://www.cve.saude.sp.gov.br/htm/hidrica/ Listeria.htm, access in February 2008.

International Organization for Standardization (ISO). Microbiology of food and animal feeding stuffs - Horizontal method for the detection and enumeration of Listeria monocytogenes - Part 1: Detection method, International Standard ISO 11290-1: 1996, Geneva, Switzerland, available in: http://www.iso.org/iso/em/ CataloqueListPage. CataloqueList?ICS1 $=07 \& I C S 2=100 \& I$, access in April 2008.

Lepper WA, Schultz AM, Curiale MS, Johnson RL (2002) Salmonella in selected foods by VIDAS immune-concentration Salmonella plus selective plate (Hektoen enteric, xylose lysine desoxycholate, bismuth sulfite): collaborative study. J AOAC Int 85:593-608.

Reis RB, Kruger CS, Maciel MS (2002) Salmonella spp. in meat products sold in the cite Cuiabá,MT, Brazil. Evaluation of research methodology. Model resistance to antimicrobial drugs. Food Sci Technol 15:74-78.

Resolution - RDC $n^{\circ} 12$, January 2 (2001) Technical Regulation on Microbiological Standards for Foods. National Agency of Sanitary Surveillance (ANIVISA), Brazil.

Silva WP, Lima AS, Gandra EA, Araújo MR, Macedo RP, Duvall EH (2004) Listeria sp. in processing of sausages in refrigerated Pelotas, RS, Brazil. Rural Sci 34:3-8.

All the content of the journal, except where otherwise noted, is licensed under a Creative Commons License CC BY-NC. 